\title{
Oncolytic Effects of the E Variant of Encephalomyocarditis Virus to Human Neuroblastoma in in Vitro and in Vivo
}

\author{
Masazumi Adachi ${ }^{*}, 1,2$, Steven E. Brooks ${ }^{1}$, Maxine R. Stein ${ }^{1}$, Bernice E. Franklin ${ }^{1}$ and \\ Francis A. Caccavo ${ }^{3}$
}

${ }^{1}$ Isaac Albert Research Institute of Kingsbrook Jewish Medical Center, USA; ${ }^{2}$ Department of Pathology, State University of New York, Downstate Medical Center, Brooklyn, New York USA; ${ }^{3}$ Public Health Laboratory City Department of Health and Mental Hygiene, New York, USA

\begin{abstract}
The oncolytic effects of encephalomyocarditis (EMC) virus on of human neuroblastoma (NB) were studied in vitro employing NB cell cultures and in vivo employing tumors grown in nude mice and nude rats. In short-term studies, human NB cell (HTB10) cultures were exposed to the virus $10^{4}$ Tissue Culture Infectious Doses (TCIDs). The TCIDs were used to titer the maximum effect of EMC virus on L-929 cells. In vitro studies showed 100\% Cytopathic Effect (CPE) at 48 hours. The CPE was used to observe pathologic effects of the cells. The in vivo studies showed necrosis and degeneration in the tumors grown in nude mice at 7 days following treatment with the virus. The nude mice exhibited a high mortality rate after exposure to the virus. The long-term studies were performed on tumors grown in nude rats, since they were more tolerant to the viral treatment. On the 58th day after the viral treatment of tumor bearing rats, 8 out of the 12 tumors had disappeared, and the remaining 4 tumors were grossly necrotic. The average size of the infected tumors was $2.13 \mathrm{~cm}^{2}$ as compared with $30.5 \mathrm{~cm}^{2}$ in the control. Microscopically the treated tumors showed severe necrosis and microcystic degeneration. The observed gross decrease in treated tumor size together with the presented light and electron microscopic studies, support the potential value of viral treatment of neuroblastoma.
\end{abstract}

Keywords: Neuroblastoma, encephalomyocarditis virus, virus inoculation, specific molecular receptor, oncolysis.

\section{INTRODUCTION}

Encephalomyocarditis (EMC) virus is in the family of picornavirus. The virion is 20 to $30 \mathrm{~nm}$ in diameter and it consists of a capsid shell of 60 subunits arranged with icosahedral symmetry around a genome that has 11 variants [1]. The virus has been investigated at our laboratory for many years [1-12]. The E variant (EMC-E) is highly neurotropic $[1-5,7,9-11,13]$ and usually not pathogenic to man $[1,14]$. The present investigation shows the oncolytic effects of the EMC-E virus on human neuroblastoma.

Neuroblastoma (NB) is one of the most frequently encountered malignant tumors in children. About $83 \%$ of cases are detected in children under the age of six [15]. At the time of diagnosis, the majority of patients (almost 80\%) have been reported to show metastasis [16]. Therefore, this virus mediated therapy of the target cells suggests a possibly effective way to treat this malignant tumor.

\section{MATERIALS AND METHODS}

Human NB cells (HTB10) were obtained from the American Type Culture Collection. The cells were main-

*Address correspondence to this author at the Department of Laboratories, Kingsbrook Jewish Medical Center USA, 585 Schenectady Ave., Brooklyn, N.Y. 11203, USA; Tel: (347) 804-6920; Fax: (718) 604-5777; E-mail: madachi@kingsbrook.org, fcaccavo@health.nyc.gov tained in T-30 flasks in Minimum Essential Medium (MEM) containing $10 \%$ fetal bovine serum (FBS). The EMC-E virus was prepared by infecting the monolayer of L-929 cells with the stock virus for 48 hours until cytopathic effect (CPE) [7] was evident. The CPE was used to observe maximum pathologic effect. The cells and supernatant media were collected and subjected to 3 cycles of freeze-thaw. The suspension was centrifuged at $2000 \mathrm{x}$ g to remove cell debris, and the supernatant fluid containing the virus was frozen in liquid nitrogen in $1 \mathrm{ml}$ aliquots. The virus suspension was titered on the monolayer of L-929 cells using the CPE endpoint technique. For in vitro studies, the NB cells were grown to $80 \%$ confluence in T-30 falcon flasks. The cultures were washed with phosphate buffered saline (Dulbeccos) and infected with $10^{4}$ Tissue Culture Infectious Doses (TCIDs) of the EMC-E virus in $1 \mathrm{ml}$ of MEM containing $10 \%$ FBS. The control cultures were handled in a similar manner but were not exposed to the virus. The control and experimental cultures were harvested at 16, 20, $24,32,40,48$ and 72 hours post-infection and processed for light and electron microscopic studies. In the in vivo studies, tumors of the NB cells were established in nude mice and nude rats by injecting $10^{7}$ of the cells into the area of the right shoulder. After 3 to 6 weeks, animals exhibited progressively growing tumors at the site of inoculation, which were confirmed to be of human origin by karyotype analysis. From these animals, 12 nude mice and 25 nude rats were selected which had the tumors of approximately $1 \mathrm{~cm}$ in diameter. The experimental subgroup of 8 mice and 16 
rats was injected in the left flank with $10^{4}$ TCIDs of the EMC-E virus. The control group which was not inoculated with the virus consisted of the remaining 4 mice and 9 rats. In the short-term studies, the 8 experimental and 4 control mice were sacrificed on the $7^{\text {th }}$ day post-viral infection. In the long-term studies, the rats were divided into two groups. The first group consisting of 4 experimental and 4 control rats was sacrificed on the $48^{\text {th }}$ day post-viral infection. The second group consisting of 12 experimental and 5 control rats was scarified on the $58^{\text {th }}$ day post-viral infection. The experiment was terminated on the $58^{\text {th }}$ day because of the large size of tumors in the control group. The tumor tissues were prepared for light and electron microscopic studies. Ultrastructural procedures were performed according to our previous publication [17]. The animals were housed and handled in accordance with the guidelines of the National Research Council.

\section{RESULTS}

In the cell cultures, after the exposure to EMC-E virus, alterations of NB cells are seen at 20 hours (Fig. 1).

The initial changes were noted in the endoplasmic reticulum (ER), Golgi complex (GC) and vacuolar formation (VF). At 24 hours, ribosomes were markedly decreased in addition to the changes of ER, GC and VF. The cultures showed $60 \% \mathrm{CPE}$ at 32 hours and 100\% CPE at 48 hours. The control cultures showed numerous small cells with the round to ovoid nuclei. One of the cultures at 32 hours is seen in Fig. (2A) as compared with a marked reduction of the treated cells at the same period in Fig. (2B). The ultrastructure of the control cells consisted of the large nuclei with the prominent nucleoli and a small amount of the cytoplasm with preserved subcellular organelles (Fig. 2C). The infected cells at 20 hours showed dilated ER and GC, and VF were noted from ER (Fig. 2D). At 24 hours, a marked reduction of the ribosomes was observed (Fig. $2 \mathbf{E}$ ) in addition to the changes of ER, GC and VF.

In the short-term in vivo studies, the gross changes of the infected and control tumors at 7 days are noted in Fig. (3).

In the treated mice tumors ranged from $0.1 \mathrm{~cm}^{2}$ to 1.7 $\mathrm{cm}^{2}$ (average: $0.77 \mathrm{~cm}^{2}$; sd: $0.59 \mathrm{~cm}^{2}$ ) as compared with the control tumors which ranged from $2.8 \mathrm{~cm}^{2}$ to $7.8 \mathrm{~cm}^{2}$ (average: $4.9 \mathrm{~cm}^{2}$, sd: $2.30 \mathrm{~cm}^{2}$ ). The treated tumors were smaller and soft, while the controls were larger and firm. Example is shown in Fig. (4).

Histological studies showed that the control tumors were markedly cellular (Fig. 5A) and revealed the preserved tumor cells in hemorrhagic areas (Fig. 5B). In contrast, the infected tumors were markedly necrotic (Fig. 5C) and showed severe degeneration with the pyknotic nuclei (Fig. 5D). Ultrastructure of the control tumors at 7 days showed the large nuclei and a small amount of the cytoplasm with preserved subcellular organelles. (Fig. 5E), while the infected cells at the same interval showed severe degeneration with a marked loss of the ribosomes and single membrane bound vacuoles from the Golgi and ER (Fig. 5F).

\section{NB CELL ALTERATION AFTER EXPOSURE TO EMC-E VIRUS}



Fig. (1). At 20 hours after exposure to E variant of encephalomyocarditis (EMC-E) virus, 18\% of neuroblastoma (NB) cells show the initial alterations in proliferation and dilation of the endoplasmic reticulum (ER) and of Golgi complex (GC) and vesicular formation (VF) with single membrane bound vacuoles from the Golgi and ER. At 24 hours, $20 \%$ of the cells show a marked loss of the ribosomes in addition to the changes of ER, GC and VF. At 32 hours, $60 \%$ of the cells reveal cytopathic effect (CPE) with severe degeneration consisting of a loss of the ribosomes, the alterations of ER, GC, VF and mitochondria (M). After 48 hours, $100 \%$ CPA is observed. 


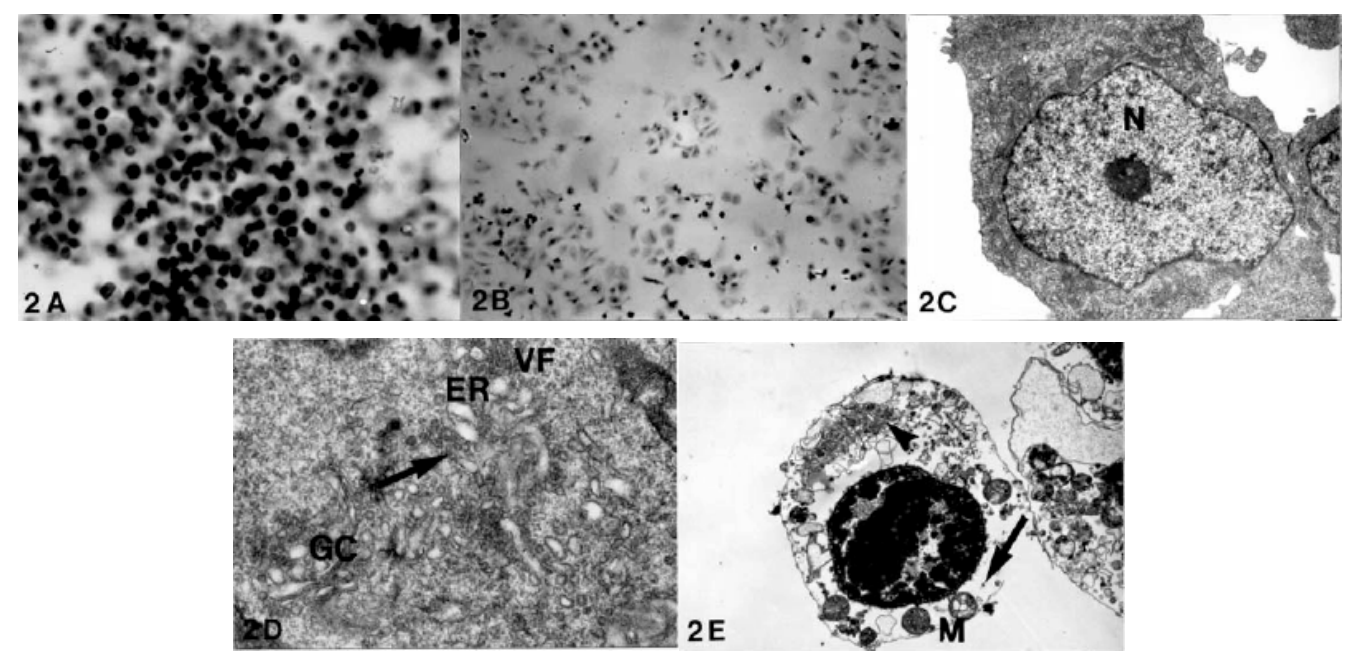

Fig. (2). Photomicrograph of NB cells in the control culture at 32 hours shows numerous cells with small and dark nuclei (A: Giemsa stain, X 960). At the same time, the infected culture shows $60 \%$ CPE (B: Giemsa stain, X 960). Ultrastructure of the control culture at 20 hours shows a large nucleus $(\mathrm{N})$ containing a prominent nucleolus and a small amount of cytoplasm with preserved subcellular organelles (C: $\mathrm{X}$ 21,000). In the infected cells, the initial changes are observed in proliferation and dilation of ER and GC and VF at 20 hours. The vesicles are originated from ER (arrow) (D: X 24,000). At 24 hours, the infected cultured cells show severe degeneration with a marked loss of the ribosomes (arrow), VF (arrowhead) and alterations of the mitochondria (M) (E: X 22,000).

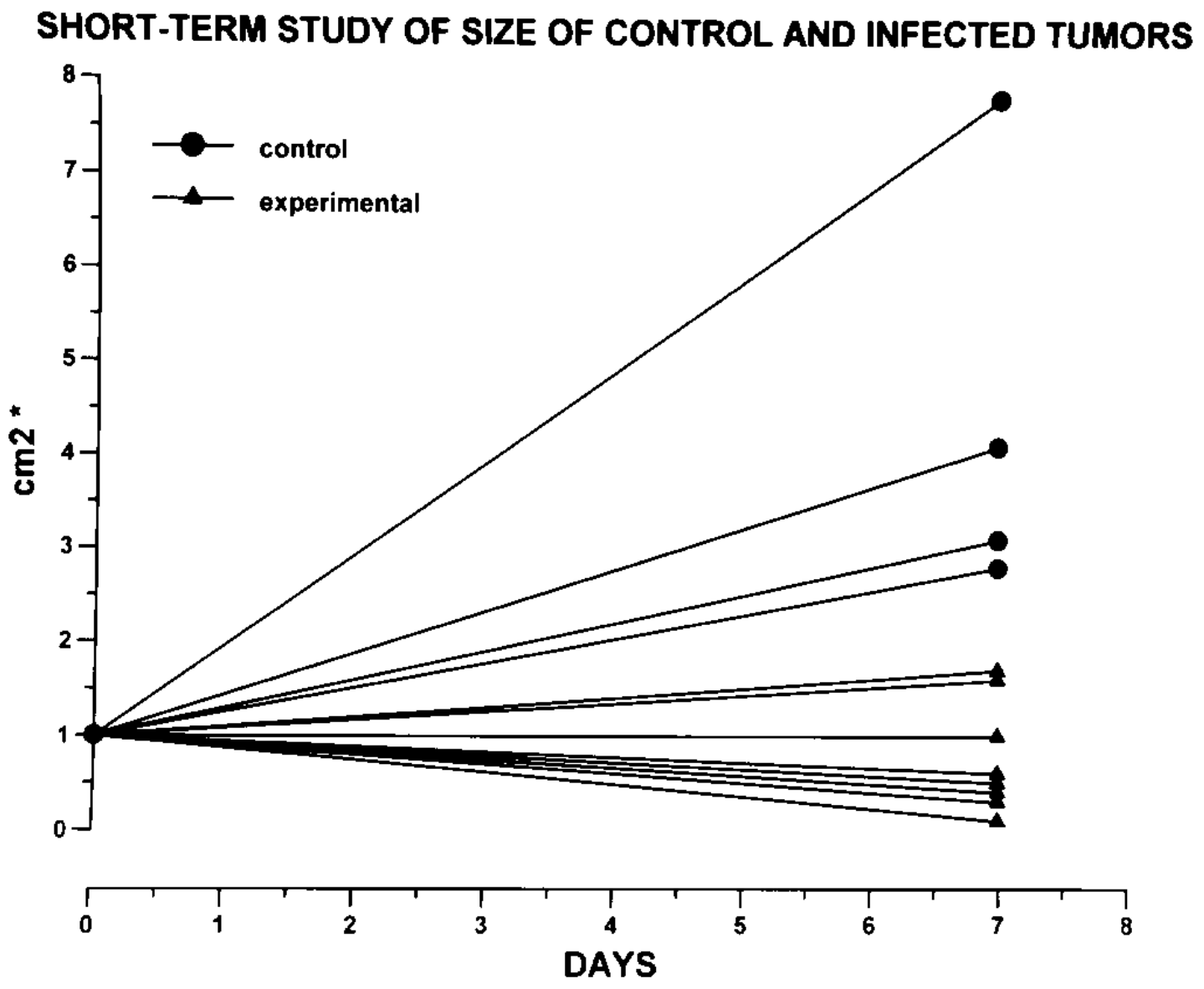

Fig. (3). The size of the tumors in the short-term study is expressed by multiplications of the length and width that correspond to the longterm studies (see Fig. 7A). The infected tumors show the size ranging from $0.1 \mathrm{~cm}^{2}$ to $1.7 \mathrm{~cm}^{2}$ (average of $0.77 \mathrm{~cm}^{2}$; sd: $0.59 \mathrm{~cm}^{2}$ ) $v s$. the controls measuring from $2.8 \mathrm{~cm}^{2}$ to $7.8 \mathrm{~cm}^{2}$ (average: $4.9 \mathrm{~cm}^{2} ; \mathrm{sd}: 2.30 \mathrm{~cm}^{2}$ ) at 7 days. 


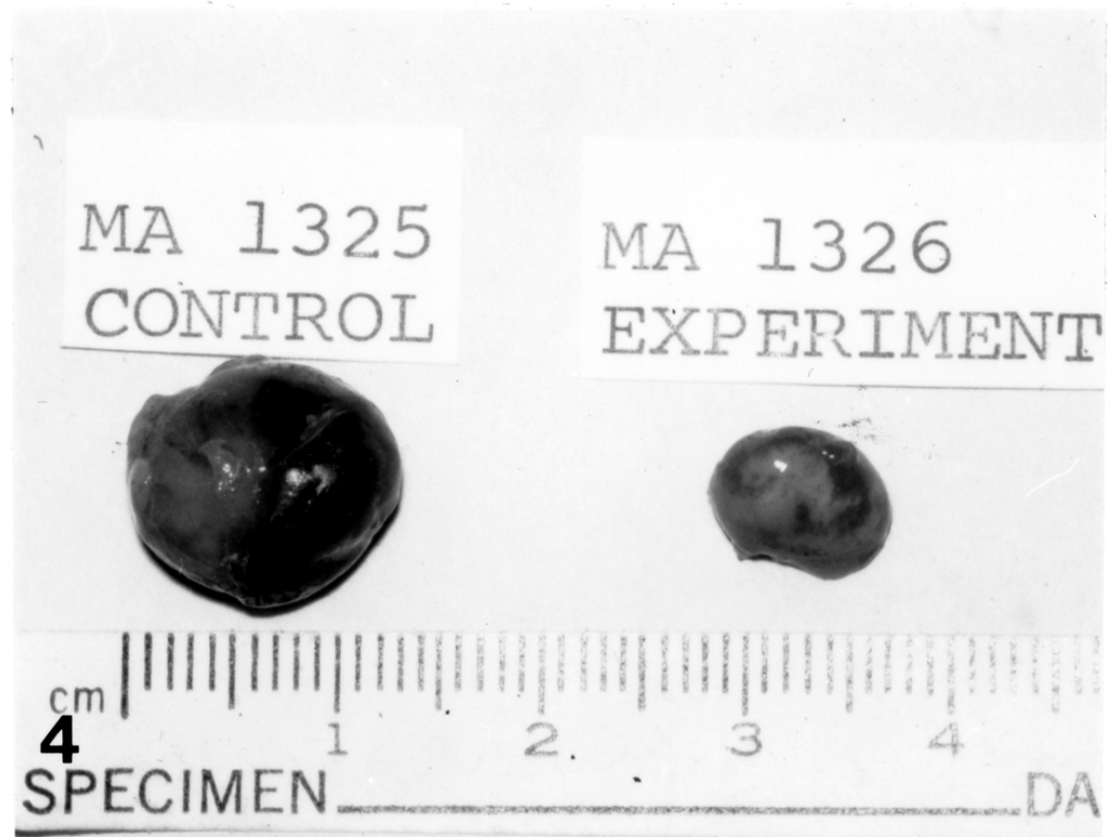

Fig. (4). The treated tumor at 7 days on the right side and the control on the left side show that the experimental tumor is smaller and soft as compared with the larger and firm control.



Fig. (5). Photomicrograph of the control tumor at 7 days shows a markedly cellular appearance and the compactly arranged dense nuclei (A: H\&E, X 960) and reveals the preserved tumor cells (arrows) in hemorrhagic areas (B: H\&E, X 960). The infected tumor at the same interval shows necrosis and dark areas (arrows) (C: H\&E, X 375), and in the dark areas, severe degeneration of the pyknotic nuclei is observed under higher magnification (D: H\&E, X 960). Ultrastructure of the control tumor at 7 days show the large nuclei with a small amount of cytoplasm with preserved subcellular organelles $(\mathbf{E}: \mathrm{X} 16,000)$. The infected tumor at the same interval reveals severe degeneration with a marked loss of the ribosomes (arrow), alterations of the subcellular organelles and accumulation of vacuoles (arrowheads) (F: X 61,000). 

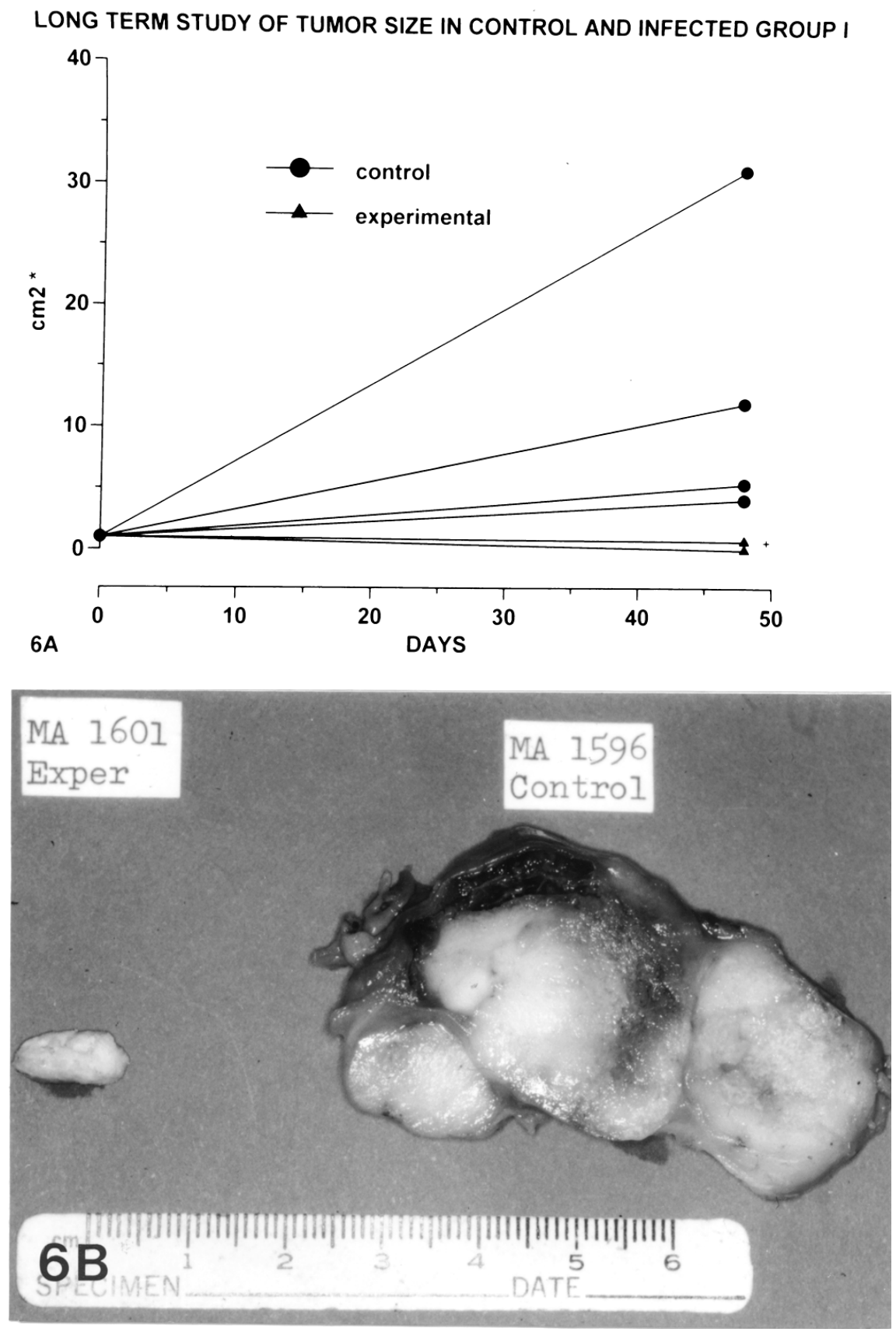

Fig. (6). In the first group of the long-term study (48 days), the tumors show variances of the size of the controls ranging from $4.1 \mathrm{~cm}^{2}$ to $31.2 \mathrm{~cm}^{2}$ (average: $13.17 \mathrm{~cm}^{2}$; sd: $12.50 \mathrm{~cm}^{2}$ ), while the infected tumors measuring from 0 to $0.7 \mathrm{~cm}^{2}$ (average: $0.52 \mathrm{~cm}^{2}$; sd: $\left.0.35 \mathrm{~cm}^{2}\right)(\mathbf{A})$. The infected tumor on the left side as compared with the control on the right side. The treated tumor is small and necrotic, while the control is massive and firm (B).

To observe the longer-term effects of the oncolytic process, the first group of the tumor-bearing nude rats was studied at 48 days. The gross changes of the infected tumors are noted in Fig. (6A). The size of infected tumors ranged from 0 to $0.7 \mathrm{~cm}^{2}$ (average: $0.52 \mathrm{~cm}^{2}$; sd: $0.35 \mathrm{~cm}^{2}$ ) as compared with the tumors in the controls which ranged from $4.1 \mathrm{~cm}^{2}$ to $31.2 \mathrm{~cm}^{2}$ (average: $13.17 \mathrm{~cm}^{2}$; sd: $12.50 \mathrm{~cm}^{2}$ ).

One of the gross examples is observed in Fig. (6B). The experimental tumor is small and totally necrotic, while the control tumor is massive and firm.
In order to increase the number of observation and to study the pattern of changes of the tumors for a longer duration, the second long-term studies group was carried out (Fig. 7). At 58 days, the size of control group tumors ranged from $12.9 \mathrm{~cm}^{2}$ to $57.1 \mathrm{~cm}^{2}$ (average: $30.5 \mathrm{~cm}^{2}$; sd: 17.99 $\mathrm{cm}^{2}$ ), while the infected group tumors ranged from 0 to 15.8 $\mathrm{cm}^{2}$ (average: $2.13 \mathrm{~cm}^{2}$; sd: $5.10 \mathrm{~cm}^{2}$ ). At the same period, eight out of the 12 treated tumors had totally disappeared, and the other two infected tumors were only trace $(0.05$ $\left.\mathrm{cm}^{2}\right)$. The remaining two tumors $\left(15.8 \mathrm{~cm}^{2}\right.$ and $9.6 \mathrm{~cm}^{2}$, 
LONG-TERM STUDY OF TUMOR SIZE OF CONTROL AND INFECTED GROUP

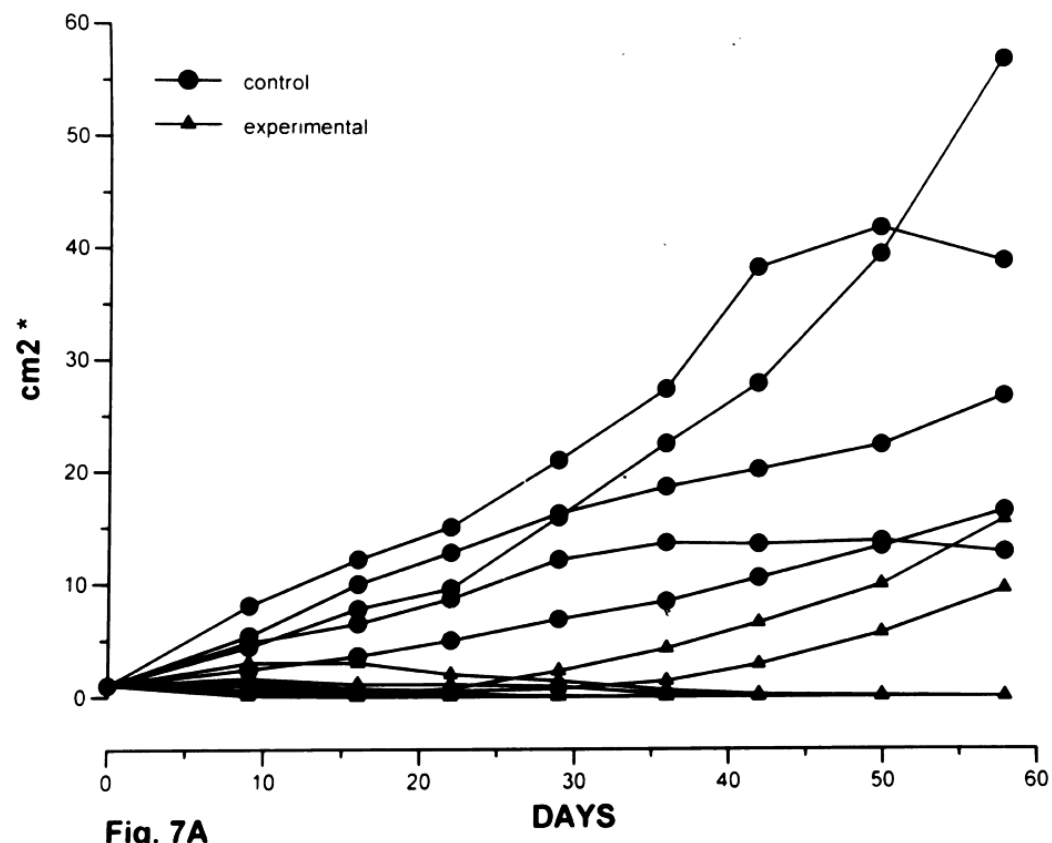

Fig. 7A

DAYS

Size: product of tumor length and width during observations of $\mathbf{5 8}$ days

LONG-TERM STUDY: AVERAGE TUMOR SIZE OF CONTROL AND INFECTED GROUP

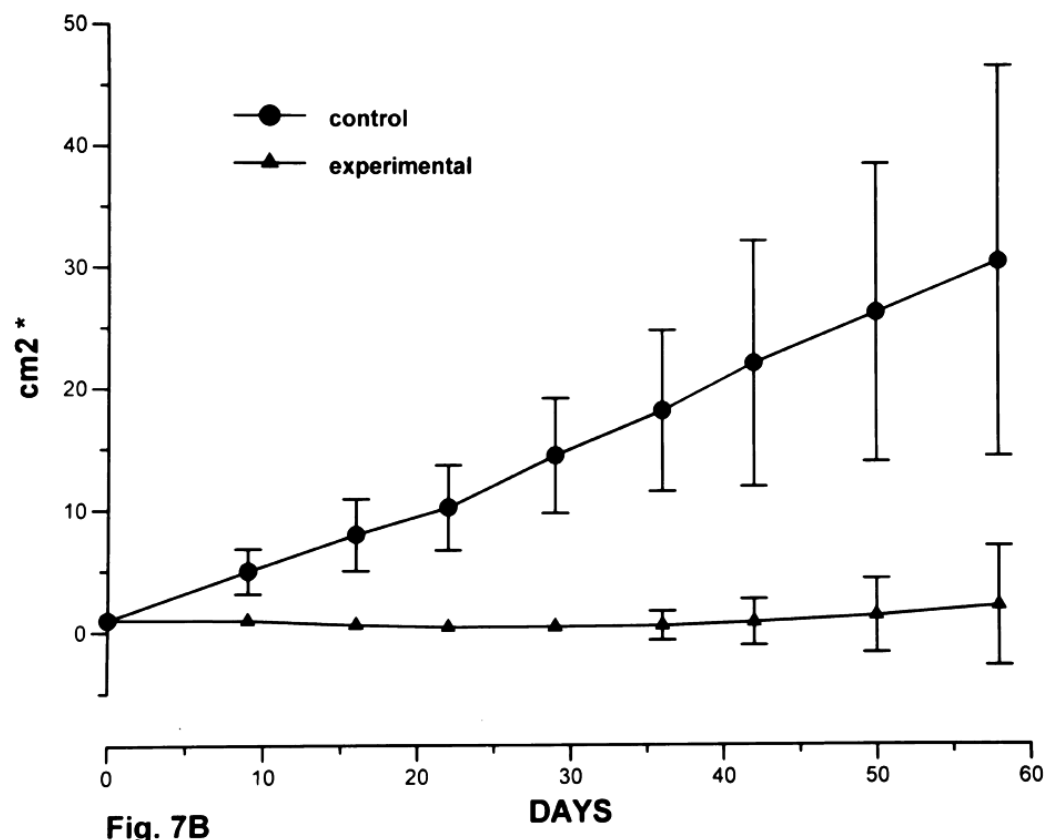

Fig. 7B

* Size: product of tumor length and width during observations of 58 days error bars indicate sd of control and experimental groups

Fig. (7). In the second group of longer-term studies (58 days)(A and $\mathbf{B}), 7$ out of the 12 infected tumors show a marked reduction of the size ranging $\left(0.1 \mathrm{~cm}^{2}\right.$ to $\left.0.6 \mathrm{~cm}^{2}\right)$ at 9 days (control: $2.4 \mathrm{~cm}^{2}$ to $8.1 \mathrm{~cm}^{2}$ ). At 29 days, 8 of the 12 infected tumors are reduced to 0 to $0.1 \mathrm{~cm}^{2}$ (control: $1.6 \mathrm{~cm}^{2}$ to $21.1 \mathrm{~cm}^{2}$ ). The definite changes are observed at 42 days. Ten out of the 12 infected tumors measure from 0 to $0.2 \mathrm{~cm}^{2}$ (control: $10.6 \mathrm{~cm}^{2}$ to $38.4 \mathrm{~cm}^{2}$ ). At 58 days, 8 out of the 12 infected tumors are completely cured, and other two tumors are only trace $(0.05$ $\mathrm{cm}^{2}$ ). The remaining two infected tumors $\left(9.6 \mathrm{~cm}^{2}\right.$ and $\left.15.8 \mathrm{~cm}^{2}\right)$ are grossly necrotic. On the contrary, the 5 controls at 58 days show a marked divergence in size ranging from $12.9 \mathrm{~cm}^{2}$ to $57.1 \mathrm{~cm}^{2}$ (A) (average: $30.5 \mathrm{~cm}^{2}$; sd: $17.99 \mathrm{~cm}^{2} v s$. infected tumors: average: $2.13 \mathrm{~cm}^{2}$; sd: $\left.5.10 \mathrm{~cm}^{2}\right)(\mathbf{B})$.

respectively) were grossly necrotic. All experimental animals were healthy during the long-term study.
Histological studies showed compactly arranged cells with frequent mitotic figures in the controls at 58 days (Fig. 


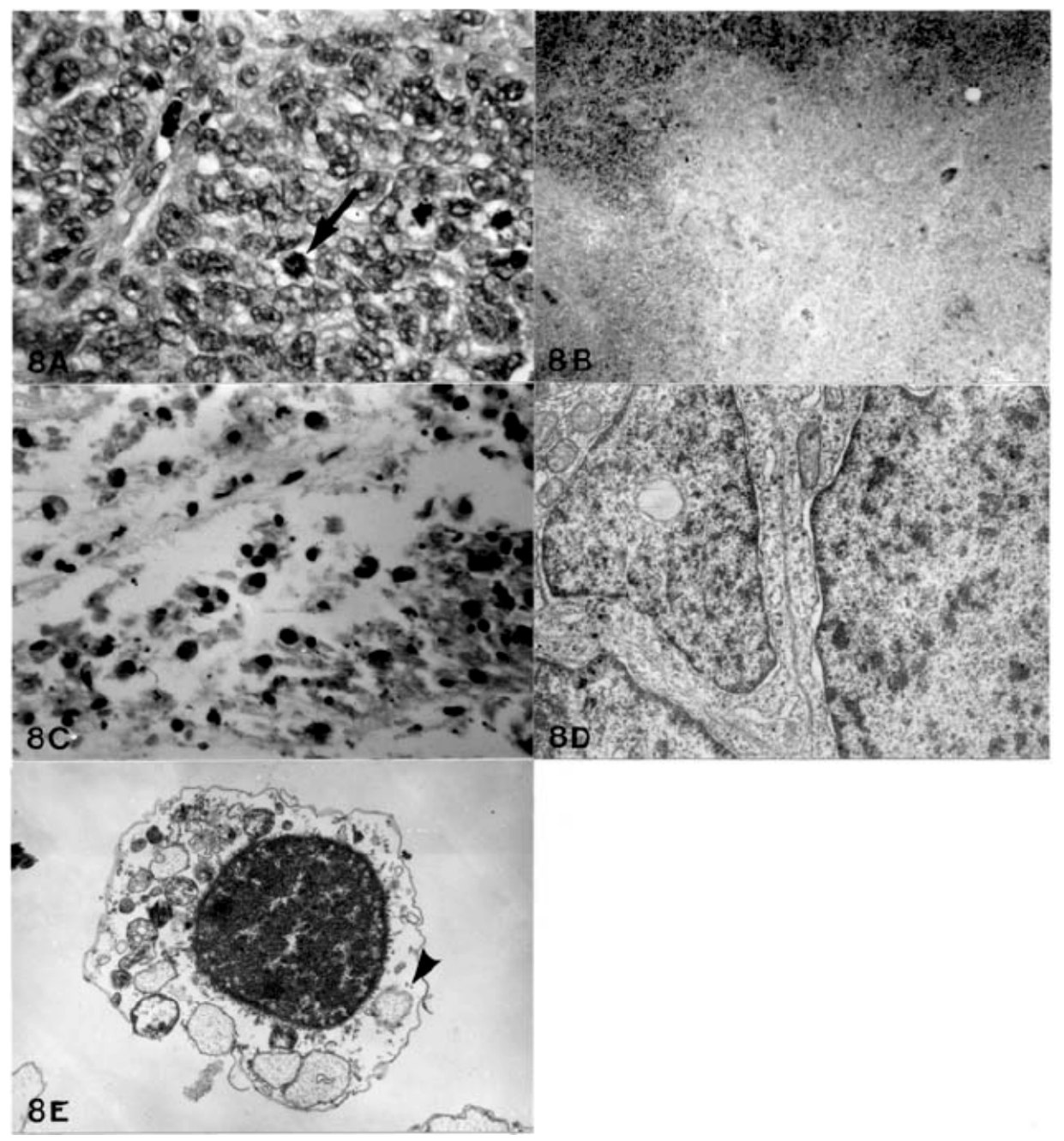

Fig. (8). Photomicrograph of the control tumor at 58 days shows a markedly cellular appearance with frequent mitotic figures (arrow) (A: H\&E, X 960), while the largest infected tumor at the same period shows necrosis (B: H\&E, X 375) and frequent microcystic changes with proliferation of macrophages (C: H\&E, X 960). Ultrastructure of the control tumor at 58 days displays compactly arranged cells with large nuclei with a small amount of cytoplasm (D: X 16,000). The largest infected tumor at the same period reveals severe degeneration with a loss of the ribosomes (arrowhead) and marked alterations of the subcellular organelles (E: X 22,000).

8A), while the large infected tumors at the same period displayed severe necrosis (Fig. 8B) and microcystic changes with proliferation of macrophages (Fig. 8C). The infected tumors of trace size at the same period were also totally necrotic. Ultrastructure of the control tumors at 58 days revealed compactly arranged cells with large nuclei with small amount of the cytoplasm with preserved subcellular organelles (Fig. 8D). The infected cells at the same period showed a marked reduction of the ribosomes with severe degeneration of the subcellular organelles (Fig. 8E).

\section{DISCUSSION}

In addition to their clinical data, molecular biology and histopathological typing of the patients predict the prognosis of NB [18-23]. Studies have shown that infants under the age of 18 months have a good clinical course, if they have a low clinical stage, hyperdiploid DNA-content and the expression of the c-trk proto-oncogene related with the high affinity NGF (nerve growth factor) receptor. On the other hand, children more than 2 year of age, with higher clinical stage, near diploid DNA-content, chromosome $1 \mathrm{p}$ deletions, N-myc gene amplification and the absence or low expression of the c-trk gene have a poor clinical course [23-28]. Signs and symptoms of the disease are related to the original site and spread of the tumor. The majority (63-76\%) of tumors originated from the adrenal medulla and sympathetic ganglia $[15,16,24-26]$. Mediastinal and abdominal masses create respiratory distress and complications of the urinary system. Neurological symptoms are also observed by compression and autoantibodies produced against the tumor [28-30]. Systemic symptoms, such as hypertension, coagulopathies and diarrhea are associated with functional hormone secretion [31-36]. Since $90 \%$ to $95 \%$ of the tumor produce catecholamines in urine, analysis of the urinary metabolites is important in addition to performing diagnostic procedures, such as computerized tomography, magnetic resonance imaging, ultrasonography and fine-needle aspiration biopsy for the diagnosis at the early stage [21, 23, 24, 37-39].

The therapeutic choices for the disease are surgery, radiation, chemotherapy and bone marrow transplantation according to clinical genetic subtypes of the tumor [21]. 
However, long-term control is seldom achieved since the tumor has a tendency to produce widespread metastases. In these cases, the oncolytic effects of the EMC-E virus is an ideal approach to treat desired target cells based on the virus special affinity for the tumor receptors. Specific molecular arrangements on the viral surface are complementary to the receptors on the target cells. These interactions are well demonstrated by the investigations of enteroviruses and coronaviruses [40-43]. Further details of the virus-receptor interactions have been described [44-49].

The EMC virus causes a high mortality rate in mice $[1,2,10,11,13]$. However, an extensive clinical study has shown that this rodent virus is not implicated in any significant pathogenesis in man [1,14]. Isolation and serologic studies of large numbers of patients with meningitis and encephalitis failed to implicate this rodent virus in human disease. The structure and functional details of picornaviruses have been demonstrated [44, 50]. During a process of the entry of the virus into cell membranes, sequential changes of the virion polypeptides occur, and interaction of the virion with specific receptors dissociates the viral polypeptides in order to permit release of the viral RNA in the host cytoplasm $[45,51]$. After the entry of the virus in the host cells, picornaviruses inhibit synthesis of host protein and direct the cells to synthesize viral proteins $[52,53]$.

Our current long-term studies have shown the $100 \%$ cure rate (total disappearance: 10 out of 12 cases; trace size and total necrosis: 2 cases) as compared with the control (average size: $30.5 \mathrm{~cm}^{2}$ ). These results suggest the concept that utilizing the EMC-E virus as an oncolytic agent may be a new effective way of virotechnology (virotech) to approach the treatment of this tumor and other malignant tumors of the nervous system.

\section{REFERENCES}

[1] Adachi M. Encephalomyocarditis virus. In: Connor DH, Chandler FW, Schwartz DA, Manz HJ, Lack EE, Eds. Pathology of Infectious Diseases; Stamford (CT): Appleton \& Lange; 1997; pp. 107-11.

[2] Adachi M. Experimental models and their treatment of some neurological disorders. Lipidosis and malignant tumors. Neuropathology 1987; 8: 47-50.

[3] Adachi M, Amsterdam D, Brooks SE, Volk BW. Ultrastructural alterations of tissue cultures from human fetal brain infected with the E variant of EMC virus. Acta Neuropathol (Berl) 1975; 32: 133-42.

[4] Adachi M, Brooks SE, Letizia I, Hoffman L, Schneck L. Destruction of LMB-astrocyoma cells in vitro and in vivo mediated by the $\mathrm{E}$ variant of encephalomyocarditis virus (EMC-E). J Neuropathol Exp Neuro (Abstract) 1982; 41: 370.

[5] Adachi M, Brooks SE, Letizia I, Hoffman L, Schneck L. Destruction of human neuroblastoma cells in vitro and in vivo mediated by the $\mathrm{E}$ variant of encephalomyocarditis virus (EMC-E). J Neuropath Exp Neurol (Abstract) 1983; 42: 351.

[6] Adachi M, Brooks SE, Rao C, Stein MR, Hoffman LM, Schneck L. Light and electron microscopic features of transformed human meningioma cells in vitro infected by the $M$ variant of encephalomyocarditis virus (EMC-M). J Neuropath Exp Neurol (abstract) 1985; 44: 315.

[7] Adachi M, Brooks SE, Stein MR, Franklin BE, Caccavo FA. Destruction of human retinoblastoma after treatment by the $\mathrm{E}$ variant of Encephalomyocarditis virus. J Neuro-Oncol 2006; 77: 233-40.
[8] Adachi M, Brooks SE, Stein MR, Hoffman L. Establishment of A variant of encephalomyocariditis (EMC-A) virus and its oncolytic effects of human astrocytoma in vitro and in nude rats. J Neuropath Exp Neurol (abstract) 1991; 50: 369.

[9] Adachi M, Brooks SE, Stein MR, Hoffman LM, Schneck L. The effect on human retioblastoma cells in vitro and in vivo after exposure to the E variant of encephalomyocaritits virus (EMC-E). J Neuropath Exp Neurol (abstract) 1984; 43: 337.

[10] Adachi M, Volk BW, Amsterdam D, Brooks S, Tanapt P, Broom JD. Light and electron microscopic studies of "nude" mice CNS after subcutaneous administration of the $\mathrm{E}$ variant of the encephalomyocarditis (EMC) virus. Acta Neuropathol (Berl) 1977; 37: 89-93.

[11] Adachi M, Volk BW, Tsai CY, Amsterdam D, Wellmann KF. Light and electron microscopic studies of mouse CNS after subcutaneous administration of the $\mathrm{E}$ and $\mathrm{M}$ variants of the encephalomyocarditis virus. Acta Neuropathol (Berl) 1973; 25:169-78.

[12] Adachi M, Brooks SE, Stein MR, Hoffman LM, Schneck L. The effect of human carcinoma (CA) and sarcoma (SA) cells in vitro after exposure to the $\mathrm{E}$ and $\mathrm{M}$ variants of encephalomyocarditis virus (EMC E and M). Fed Proc (abstract) 1986; 435: 956.

[13] Craighead JE. Pathogenicity of the M and E variants of the encephalomyocarditis virus. I. Myocardiotropic and neurotropic properties. Am J Path 1966, 48; 333-45.

[14] Meyer HM Jr, Johnson RT, Craford IP, Dascomb HE, Rogers NG. Central nervous system syndromes of "viral" etiology. A study of 713 cases. Am J Med 1960; 29: 334-47.

[15] DeLorimier AA, Bragg KU, Linden G. Neuroblastoma in childhood. Am J Dis Child 1969; 118: 441-71.

[16] Jennings RW, LaQuaglia NP, Leong K, Hendren WH, Adziok NS. Fetal neurblastoma: prenatal diagnosis and natural history. J Pediatr Surg 1993; 28: 1168-74.

[17] Adachi M, Volk BW. Methodology: electron microscopy. In:Volk BW, Schneck L, Eds. The Gangliosidoses. NY: Plenum Press, 1975; pp. 261-64.

[18] Brodeur GM. Neuroblastoma-clinical application of molecular parameters. Brain Pathol 1990; 1: 47-54.

[19] Brodeur GM. Neuroblastoma: clinical significance of genetic abnormalities. Cancer Surv 1990; 9: 673-88.

[20] Brodeur GM, Nakagawara A. Molecular basis of clinical heterogeneity in neuroblastoma. Am J Pediatr Hematol Oncol 1992; 14: 111-16.

[21] Brodeur GM, Pritchard J, Berthold F, et al. Revisions of the international criteria for neuroblastoma diagnosis, staging, and response to treatment. J Clin Oncol 1993; 11:1466-77.

[22] Evans AE, D'Angio GJ, Propert K, Anderson J, Hann HW. Prognostic factor in neuroblastoma. Cancer 1987; 59: 1853-59.

[23] Koh PS, Raffensperger JG, Berry S, et al. Long-term outcome in children with opsoclonus-myoclonus and ataxia and coincident neuroblastoma. J Pediatr 1994; 125: 712-16.

[24] Stowens D. Neuroblastoma and related tumors. Arch Pathol 1957; 63: 451-59.

[25] Vandernberg Sr, Herman MM, Rubinstein LJ. Embryonal central neuroepithelial tumors: current concepts and future challenges. Cancer Metastatis Rev 1987; 5: 343-65.

[26] Cooper MJ, Hutchins GM, Cohen PS, Helman LJ, Mennie RJ, Israel MA. Human neuroblastoma tumor cell lines correspond to arrested differentiation of chromaffin adrenal medullary neuroblasts. Cell Growth Differ 1990; 1: 149-59.

[27] Adams GA, Shochart SJ, Smith EI, et al. Thoracic neuroblastoma a pediatric oncology group study. J Pediatr Surg 1993; 28: 372-77.

[28] Altman AJ, Schwartz AD. Malignant diseases of infancy, childhood and adolescence. 2nd ed. Philadelphia: Saunders 1983.

[29] Fisher PG, Wechsler DS, Singer HS. Anti-Hu antibody in a neuroblastoma- associated paraneoplastic syndrome. Pediatr Neurol 1994; 10: 309-12.

[30] Grosfeld JL, Skinner MA, Rescorla FJ, West KW, Scherer LD 3rd. Mediastinal tumors in children: experience with 196 cases. Ann Surg Oncol 1994; 1: 121-7.

[31] Bjelleup P, Theodorsson E, Kogner P. Somatostatin and vasoactive intestinal peptide (VIP) in neurblastoma and ganglioneuroma: chromatographic characterization and release during surgery. Eur J Cancer 1995; 31A: 481-5.

[32] Bolkenius M, Daum R. Adrenal tumors. Prog Pediatr Surg 1983; 16: 113-6. 
[33] Rauh W. Endocrine and neurogenic hypertension in children. Monatsschr Kinderheilkd 1983; 131: 825-9.

[34] Scheibel E, Rechnitzer C, Fahrenkrug J, Hertz H. Vasoactive intestinal polypeptide (IP) in children with neural crest tumors. Acta Paediatr Scand 1982; 71: 721-5.

[35] Weinblatt ME, Heisel MA, Siegel SE. Hypertension in children with neurogenic tumors. Pediatrics 1983; 71: 947-51.

[36] Williams TH, House RF Jr, Burgert EO, Lynn HB. Unusual manifestations of neuroblastoma: chronic diarrhea, polymyocloniaopsoclunus, and erythrocyte abnormalities. Cancer 1972; 29: 47580.

[37] Joshi VV, Silverman JF, Altshuler G, et al. Systemalization of primary histopathologic and fine-needle aspiration cytologic features and description of unusual histopatholoic features of neuroblastic tumors: a report from the Pediatric Oncology Group. Hum Pathol 1993; 124: 493-504.

[38] Taxy JB. Electron microscopy in the diagnosis of neuroblastoma. Arch Pathol Lab Med 1980; 104: 355-60.

[39] Temple S. Characteristics of cells that give rise to the central nervous system. J Cell Sci 1990; 97: 213-8.

[40] Crowell RJ, Landau BJ, Philipson L. The early interaction of coxsackievirus B3 with Hela cells. Proc Soc Exp Biol Med 1971; 137: 1082-8.

[41] Dale S. Early events in cell-animal virus interations. Bacteriol Rev 1973; 37: 103-35

[42] Lonberg-Hom K, Korant BD. Early interaction of rhinoviruses with host cells. J Virol 1972; 9: 29-40.

[43] McLaren LC, Holland JJ, Syverton JT. The mammalian cel-virus relationship. I. Attachment of poliovirus to cultivated cells of primate and non-primate origin. J Exp Med 1959; 109: 475-85.

[44] Crowell RL. Comparative generic characteristics of picornavirusreceptor interactions. In: Beer RF, Bassett EG, Eds. Cell membrane receptors for viruses, antigens and antibodies, polypeptide hormones and small molecules. New York: Raven 976; pp.179202.

[45] Crowell RL, Siak JS. Receptor for group B coxsackie viruses: characterization and extraction form Hela cell membranes. In: Pollard M, Ed. Perspectives in virology. NY: Raven 1978; Vol 10: pp. 39-53.

[46] DeLarco JE, Todaro GJ. Membrane receptors for murine leukemia viruses: Characterization using the purified viral envelope glycoprotein. Cell 1976; 8: 365-71.

[47] Lonberg-Hom K. The effects of concanavlin A on the early events of infection by rhinovirus type 2 and poliovirus type 2 . J Gen Virol 1975; 28: 313-27.

[48] Oie HK, Gazdar AF, Lalley PA, et al. Mouse chromosome 5 codes for ectopic murine leukemia virus cell-surface receptor. Nature 1978; 274: 60-2.

[49] Ruddle NH, Conta BS, Leinward L, et al. Assignment of the receptor for ectotropic murine leukemia virus to mouse chromosome 5. J Exp Med 1978; 148: 451-65.

[50] Schaffer FL, Schwerdt CE. Crystallization of purified MEF-1 poliomyelitis virus particles. Proc Natl Acad Sci USA 1955; 41 1020-3.

[51] Philipson L, Beatrice ST, Crowell RL. A structural model of picornaviruses as suggested from an analysis of urea-degraded virions and procapsides of coxsackievirus B3. Virology 1973; 54: 69-79.

[52] Baltimore D. The replication of picornaviruses. In: Levy JB Dekker, Ed. Biochemistry of viruses. NY: Marcel 1969: pp. 10176.

[53] Lawarence C, Thach RE. Encephalomyocarditis virus infection of mouse plasmocytoma cells. I. Inhibition of cellular protein synthesis. J Virol 1974; 14: 598-610.

(C) Adachi et al.; Licensee Bentham Open.

This is an open access article licensed under the terms of the Creative Commons Attribution Non-Commercial License (http://creativecommons.org/licenses/by$\mathrm{nc} / 3.0 /$ ), which permits unrestricted, non-commercial use, distribution and reproduction in any medium, provided the work is properly cited. 